MARKETING AND BRANDING
RESEARCH

\title{
Comparison of stock valuation models with their intrinsic value in Tehran Stock Exchange
}

\author{
Ali Amiri ${ }^{1}$, Hamid Ravanpaknodezh ${ }^{2}$, Akbar Jelodari ${ }^{3 *}$ \\ ${ }^{1} \mathrm{PhD}$ in Accounting, Faculty Member, Islamic Azad University, Bandar Abbas, Iran \\ ${ }^{2} \mathrm{PhD}$ in Accounting, Faculty Member, and director of Qeshm Institute of Higher Education, Hormozgan, Iran \\ ${ }^{3}$ MA Student of financial Management, Qeshm Institute of Higher Education, Hormozgan, Iran
}

Correspondence:

akbar.jelodari@gmail.com

\begin{abstract}
stratified random sampling, each industry was selected as a category and using Cochran formula, sample size of 40 participants was determined from each category. The data analysis indicated that the price-to-book ratio ( $\mathrm{P} / \mathrm{B} \mathrm{ratio}) \mathrm{had}$ the highest adjustment factor and had been set as the best stock valuation model.
\end{abstract}

Keywords:

Stock, Stock Valuation Models, Intrinsic Value of the Market

Correspondence:

CAIMI Journals

\section{Introduction}

Daily, hundreds of companies enter into stock market by issuing stocks for the first time to raise the required capitals for the expansion of their business. That is why it is important for companies that set price for the stocks to represent the true value of assets and development 
and growth opportunities in the future. This is despite the fact that the studies done by many researchers in the field of issuing securities, especially stock indicate; they state that the price set for the companies' stocks and securities with their intrinsic value is not favorable and makes investors to increase their profits in short term by buying stocks of the company and subsequently benefit from abnormal rate of returns. It is clear that this issue apart from distorting the market performance brings large losses for the enterprises issuing stocks.

Changes in stock prices are the most important topics of interest for every investor. Investors who invest for long-term goals are sensitive to changes of stock price and react to them. Change in prices is an important and effective source of information for assessing firms' situation, evaluating comparatively other enterprises, estimating managers' performance, and most importantly is influential in investment decisions.

Fluctuation of stock price on the stock exchange is ordinary and necessary. The stock price is affected by many factors including internal and external organizational factors and each of these factors affect it differently. Predicting price changes requires behavioral patterns of stock prices. If the behavioral patterns be detectable, shareholders with an assessment of their stocks and other stocks in the market can choose the best stocks; and consequently, they can keep, sell, or partly replace their stock with other stocks. Investors deserve to receive timely, relevant, and effective information. Changes in stock prices are an important source of information and help them to evaluate the entity's situation and managers' performance and decisions. So the most important thing for companies and investors is to predict price changes.

In the $60 \mathrm{~s}$, studies were done to predict prices, find the impact of information on prices, on stock market behavior, and finally it was aimed to find out how to change the price and the relationship of these changes in capital market. The result of this research led to the creation of a hypothesis about how the capital market functions as the efficient market. The aim of this study was to assess the reaction of the stock market in the acquisition and processing of information and the urgent impact of information on the stock price without a certain tendency.

Market efficiency hypothesis is the result of Fama's research (1991) which confirms the lack of correlation between the prices and it is because of the full and unbiased distribution of information in the market and no relevant information should be overlooked. Since the introduction of the above hypothesis, the capitalist countries gave special attention to efficient capital market. In such a situation (functioning of the market), the price of securities will be determined fairly and investors will gain more confidence. Otherwise, when there is lack of effectiveness, it is possible to predict the price and consequently make a group to benefit at the expense of others through transactions process. Note that the efficiency issue is not just black or white. The market is not perfectly efficient or completely inefficient.

For the development of stock exchange as an organized institution for the capital market, the behavior of stock prices is an important issue for buyers, brokers, stock managers, and government. Therefore, there is an urgent need to understand the underlying factors explaining the price of these assets. Financial theory states that the value of a stock is equal to the present value of its expected earnings. The ambition to apprehend the stock pricing in the lack of a uniform and same set of variables which are illustrative for future assumed results 
lead to quick appearance of stock valuation models while nearly all stock valuation models and frameworks are based on a theoretical framework. In today's world, privatization and turning vastly towards buying and selling stocks requires extensive research in the field of finance and accounting. One of the key areas is the studies done to determine the factors affecting stock prices. Iran's stock market is increasingly growing and it is one of the most important mechanisms in the development of the economic structure and its importance is growing day to day. One reason for the continuous increase of companies listed in the stock exchange is the government's privatization policy with the aim of reducing state administration and transferring state-owned enterprises to the private sector. Another reason relates to non-member private enterprises which try to achieve acceptable management standards and financial reporting as soon as possible to gain access to this large capital market. In other countries, the companies that want to determine the value of stocks and sell their stocks to the public use the services offered by the financial institutions and investment banks. In Iran, due to the nascent capital market and the lack of investment banks, Tehran Stock Exchange is practically responsible for determining the base price. Any inaccuracy in this stage can lead to disastrous results.

In the case of licensed companies, the stock must be priced by the valuation or pricing committee of the stock exchange and the prices must be released later on. But often after a short time, automated process of stock price formation in the stock exchange which is due to the supply and demand of stocks as well as expectations of shareholders and investors causes significant changes in the price offered by the pricing committee. As a result, stock prices face significant rise or fall in the market. It seems that this is due to the inconsistency between the valuation models used in the pricing committee of stock exchange with governing thought and conditions in market. The aim of this study was to compare the price of stocks in Tehran Stock Exchange with the prices obtained from theoretical models of stock valuation. In this study, variables such as earnings per share, net profit margin, the percentage of dividend, beta, dividend growth rate, benefits paid, and the economic environment are tested. This research can be used by individuals, institutions and different organizations. The organizations which use the results of this research are Stock Exchange, investment companies, finance companies, brokerage firms, creditors, banks, and shareholders. The government is one of the main beneficiaries which for privatizing and transferring the stateowned shares need a model of determining the price of the stock in a way that both sides (government and buyer) could make profit. Investors buy stocks in the pursuit of higher returns than other investment opportunities. In this regard, the main factor for the transfer of capital stock is the price of the securities offered in stock exchange which are determined at the outset. In inefficient markets, prices of the day on securities are highly far from their inherent price and the information distributed in the market does not affect the price of securities. This means that in such a market, systematic investment decisions and allocation of capital requires stock valuation using valid scientific methods; because the market price is not trustable or at least discovering price in short-term cannot be achieved due to the fluctuation and unrealistic price in the market. 
Privatization and stock valuation of companies subject to transferring capital stock are two important issues on the country. In recent years in many countries regardless of the level of development and the political situation, the wide range of public sector assets is transferred to the private sector. It is believed that privatization involves issues such as economic incentives, attracting management and technological resources of the private sector, expanding ownership in the form of shareholdings, and reducing enormous debts of the public sector.

Public offering of stocks is one of the most common methods of transferring state-owned enterprises to the private sector. In this way, the government offers all or a large part of its transferable stocks to the public. The only thing that government or the organization of transferring stock can do is to specify the base price of its stocks in the Stock Exchange and offer for sale to the general public. Therefore, in Iran during the transfer of profit-seeking enterprises especially at a time when the stock exchange draws particular interest from investors and government circles, pressure from the privatization organization on government to transfer the stocks has been increased and evaluating and determining the base price for profit-seeking enterprises that is subject to privatizing is important. Being the economy in the transition period creates situation that evaluating and determining the base price for the companies subject to transfer becomes very difficult.

There are generally two approaches to stock assessment: Some experts believe that the prices of company stocks are obtained from the total price of the components of its assets (land, buildings, plant, and machinery) after deducing debts (first theory); and some of the experts believe that given the uncertain life of companies, the stocks of a company are equal with the present discounted value of its cash earnings which is due to the risk factor and the cost of financing (second theory). In other words, when the assets of a company can create value for the company's stock, the company's management makes best use of that asset and brings good returns for shareholders. So, if because of external or internal factors the level of profitability be low, the value of its stocks will be lower.

According to the second theory, determining the value of the stocks subject to transferring because of different levels of performance in different years and due to the problems presented above in Iran is difficult. Even in Western capitalist countries that have developed capital markets and their stocks traded more than 200 years, determining the value of their stocks are confronted with many problems.

In most developed countries, stock valuation in companies that intend to sell their stocks to the public is done by financing institutions or investment banks. These institutions having a long experience in determining value of their stocks determine stock prices taking into account the general situation in the capital market, analysis of financial condition and facilities of the country, and the outlook for profitability of the corporate as well as the similar company's stock price. In addition to stock valuation, these institutions are responsible to offering and selling stocks to the public. The price of stocks of companies whose stocks are first offered to the public is usually considered less than the stock price of the companies that have a long history of stock trading. It is so because of the high risk and concerns about the absence of transaction prices and also due to the uncertain liquidity. Since other countries have certain rules on the disclosure of comprehensive information in the 
companies whose stocks are offered to the public, this institutions are responsible for providing information manual about the company's affairs. This information is provided by its validity and its integrity is confirmed by the authorities; therefore, to a large extent people's confidence to invest in the stocks are increased.

In Iran due to the nascent capital markets and lack of investment banks, Tehran Stock Exchange is held responsible for determining the base price. Unfortunately, the lack of full respect for scientific principles and regarding state institution's view in terms of stock valuation, have caused the price set for the stocks has no close and systematic association with the value of such stocks.

Regarding the assumption of continuing activities of companies and being unlikely to dissolve companies, the value of stocks are usually determined on the basis of the time period of shares value receipt and the risk of future profits. For those shareholders who gain special interests through the control of the company, the value of company stock could be further from the present and future value.

The most important task of the stock exchange is creating a consistent and efficient market for securities, so that at any moment securities can be traded with a fair price close to the previous transaction price. Therefore, the stock exchange must be able to provide sufficient liquidity for investors. In such a market, investors will be able to convert their securities into cash immediately or their assets will be invested in securities.

Another important task of the stock exchange is determining the price of securities. Price in this market is determined based on purchase and sale orders (supply and demand) of securities. All orders for the purchase and sale of securities are sent to the stock exchange from around the country and stock prices are determined according to the amount of supply and demand. According to the information published on the market, an efficient market should continuously evaluate securities and reflect its effect on prices of securities; in other words, in the stock exchange, price of securities shows sensitivity to changes and various events.

A variety of internal and external factors affect stock price. Internal factors include rate of return on assets, the amount of development plans and its rate of return, rate of financing or capital costs, management function, and the company's cash flow dividend, respectively. External factors involve inflation, the security of investment, tax rate on profits from stock, weaknesses and duplication of information, a brief coefficient, executive and regulatory risks, and stagnation.

In stock exchange, there is a lot of sensitivity to the price trend. This led to regular analyses of developments relating to such a phenomenon. Securities analyst uses two methods for determining the value of the common stock. The first view is technical analysis or the Chartists. Chartists believe that there is no possibility to calculate the intrinsic value of stock. They believe that the market has undergone a quasi-psychological state and history always repeats itself. Historical trend of patterns repeat pricing process at any time. By examining past trends, future trends can be predicted. The aim is not just to determine longterm changes, but the purpose is the use of short-term opportunities and charting and obtaining process is the most famous used tool. The second view is the fundamental analysis 
or fundamentalists' views. This group believes that per share has intrinsic value. To determine the intrinsic value, it is necessary to study the firm and the whole economy deeply relying on all received information. They believe that stock prices have no specific trend and by studying historical trends, predicting the future price is impossible. Following this, the stock market has no memory and prices vary randomly. They consider chartists the diviners of the profession.

\section{The Method for Determining Price in Tehran Stock Exchange}

In Tehran stock exchange pricing committee is responsible for determining the base price for the stocks listed in stock exchange. The formula used to determine the base price is as follows:

Value per share $=\frac{E R S 1}{k}$

In this formula, EPS1 is the forecast of earnings per share in the following year and $\mathrm{k}$ is the discount rate or expected rate of return to shareholders. Three different rates $(12 \%, 15 \%$, and $18 \%$ ) are respectively applied to determine the base, average, and ceilings prices. Recently, due to the stock market downturn and increased risk, $\mathrm{K}$ rates have been increased.

To be able to do its duty properly, stock exchange must be effective and efficient. Many requirements which are necessary for an efficient stock exchange are as follows (Rao Romesh, 1989):

1) Ease of flow and broad access to information of market for the public

2) The balance between risk and return

3) Determining the price of securities based on supply and demand

4) The lack of a significant difference between price and value inherent in securities

5) The capability of market liquidity

6) No individual's ability to unilaterally change in prices

These features, in fact, are created because of perfectly competitive markets which are highly similar to the stock exchange market. Therefore, a high degree of efficiency is resultant from a high degree of proximity of stock exchange market to perfectly competitive markets.

\section{The Literature Review}

One of the important questions raised for the form of financial investment decisions is related to the nature and behavior of securities prices, in particular, stocks. In this regard, various theories were proposed to make systematic the relationship between stock prices and factors affecting it such as return and risk. And, several studies were conducted to determine the stock price in Tehran Stock Exchange.

\section{The Relationship between Systematic Risk of Common Stock and Stock Returns}

In This study, monthly returns and systematic risk factor of the stocks of companies listed in Tehran Stock Exchange were calculated for a period of 48 months from 2002 until the ends 
of 2006. Then, the beta of these companies was divided for 8 portfolios and SML capital market line is drawn. Regarding the correlation between systemic risk and portfolio efficiency, the results showed a significant correlation between systemic risk and stock returns (Shafizadeh, 1996).

\section{The Relationship between the Stock Price and the Intrinsic Value of Companies Listed in Tehran Stock Exchange}

This study included all companies in Tehran Stock Exchange during 2003-2006. In this study, stock values of companies that had significant $\beta$ were calculated and finally the relationship between price and value was tested. The result indicated that the null hypothesis was rejected and there was a significant correlation between price and value of stocks (Salami, 2002).

\section{Evaluation of the Tendency of Systemic Risk of the Stocks in Tehran Stock Exchange}

This study included all companies in Tehran Stock Exchange during 2003-2007 and future betas of companies present in Tehran Stock Exchange were estimated based on adjusted historical betas, i.e. after adjusting for historical betas based on current and expected changes in the conditions and also the basic features of the company, the future beta is estimated. The result can be expressed as follows:

1. The systemic risk of company's stocks in Tehran Stock Exchange tended to a systemic risk of the market over time;

2. The distribution of stock returns of most companies over 2003 to 2007 was abnormal;

3. Simple regression model which was fitted to estimate the beta of a large number of companies was not significant (Panahi Jahanabad, 2007).

\section{Determining the Intrinsic Value of the Stocks of Companies Listed in Tehran Stock Exchange for the Automobile Industry}

This study is based on logical and reasonable relations of traded prices of common stock of the company with their intrinsic value. In this study, the intrinsic value of the companies was calculated by different techniques such as discounted cash flows and $\mathrm{H}$ method. The result represented a logical relationship of the traded prices of stocks with the intrinsic value of company's stock of SAIPA and Iran Khodro as the largest Iranian auto manufacturer (Tahmasbi, 1998).

Therefore, during recent years, many articles about pricing and stock price prediction developed that their aim was to offer models for the prediction of stock prices by regression model, neural networks, and other methods. In this context, Stewart (1990) examined the relationship between economic benefits and the market value of the company. He placed a sample of 613 companies in 25 portfolios and ranked them in terms of economic benefits and changes in the economic benefit. He found a strong correlation between economic profit and market value added (MVA) as well as a stronger correlation between changes in economic benefits and changes in the MVA. This deep correlation led the researchers to conclude that the MVA is largely consistent with economic benefits (Stewart, 1990). 
Damodaran (1996) proposed the model of stock valuation i.e. stock price to sales (P/S) model that depends linearly on four main variables. These variables include the percentage of dividend, dividend growth rate, beta, and profit margins. Damodaran's model accounted $26 / 77 \%$ of the price changes for 1995 . He also found that the coefficients of all variables were consistent with their expectations.

Vaez, Abzari, and Jamali (1991) investigated the predictability of stock price, the efficiency rate, and how expectations are formed in Tehran Stock Exchange using the capital asset pricing model. First, the intrinsic value of the company's stocks were examined by using CAPM model; then, the relationship between the stock price and intrinsic value of stock were regarded for companies that their systematic risk was significant. In this study, the relationship between current and past returns of stock was tested to evaluate the performance and efficiency of the stock market. Finally, the formation of expectations using ECM model was investigated. The results revealed that within CAPM model, stock price changes was due to the intrinsic value of a stock.

Blum and Friend (1973) as the first researchers of CAPM attempted to estimate beta and then, they formed portfolio based on the obtained beta. They placed the stocks which had low beta in one portfolio and stocks with high beta on other portfolio. Their study showed that through the creation of portfolio and diversification, investment risk is reduced. Although CAPM model states that in the calculation of the expected return, the width of the source is the risk-free rate of return and the beta coefficient is the expected market return minus the risk-free rate of return, however, researchers, namely Blume and Friend (1973), Fama and MackBeth (1973), and Fama and French (1992) revealed that the risk-free rate of return was greater than the width of the source and Stambaugh (1982) in his study on the width of the source showed that source width of the time-series regression for securities with low beta was positive and for securities with large beta it was negative.

In 2004, CRPS Research Center estimated stocks beta of companies present in stock markets such as NYSE, AMEX, NASDAQ for the years 1928-2003; then, it held 10 portfolios based on the ranking of betas of companies, and after that it calculated the rate of return on portfolio for the coming 12 months. This process was repeated for the years 1928 2003. The study indicated that the average of portfolio had inverse relationship with the historical beta. Sharpe's CAPM model says that source width is equal to the risk-free rate of return and the slope coefficient of the equation of the expected rate of return is equal to the excess of the expected rate of return in the market. CRPS Research Center used interest rates of America Treasury as risk-free return to estimate the regression of expected return during the years 1928-2003. The study found that the relationship between beta and average return for the portfolio was much less than Sharp's prediction. Returns for portfolio with low-beta were very high and for the portfolio with high beta was very low. For example, it was predicted that returns of the lowest beta portfolio (3/8\%) was almost $11 \%$ and returns with the highest beta portfolio $(8 / 16 \%)$ was equal to $13 / 7 \%$.

Fama and MacBeth (1973) assessed the linear relationship of beta and expected rate of return. For this purpose, they inserted square beta into the model and then, they analyzed their significance. Their study indicated that this parameter did not explain the expected rate of return. 
Some researchers made objection to CAPM. In the first study done by Basu (1997), stocks were arranged based on the price per share ratio (E/P). Then, he showed that the future returns for share with a high ratio $\mathrm{E} / \mathrm{P}$ were higher than the returns predicted by the CAPM model. In order to reject the CAPM, Banz (1981) confirmed that in the capital market, the average return of stocks of small companies was more than the amount predicted by the CAPM model.

Fama and French (1995) offered empirical evidence of CAPM failure. They stated that the company size, the ratio of earnings of per share to the share price $(\mathrm{E} / \mathrm{P})$, the ratio of debt to companies' assets and the ratio of book value to market value, and the amount of explaining the expected return were increased by ß. Chan, Hamao, and Lakonishok (1991) found a strong correlation between the book value to market value $(B / M)$ of stock and average returns for the Japanese market. Also, Capaul, Rowley, and Sharpe (1993) revealed the same effect of ratio of book value to market value of the stock (B / M) for the stock market of four European countries. Sorensen and Williamson (1980) valued 150 stocks of companies listed in S \& P400 in December 1980 using the present value of dividends. They comprised 5 portfolios enjoying the difference between the market price and the values obtained from the model. They observed that the portfolio which its intrinsic value exceeded the market value, revealed positive deviation of returns by the capital asset pricing model whereas the portfolio which its intrinsic value was less than market value showed a negative deviation.

Kaplan and Roback (1995) offered evidence of the ability of the discounted cash flows model in explaining exchange value for 51 samples of stocks. The results showed that the median of the estimate of the value of the cash flow's model were $10 \%$ of the market value. And, this model functioned better compared to models based on comparable companies.

Frankel and Lee (1998) in a study found that the abnormal returns compared to estimations based on earnings and book values or a combination of both explained a considerable part of stock price changes.

Tehrani (1995) examined factors affecting the stock price in the stock exchange such as earnings per share, dividends, and growth rate and he found that earning per share and dividends on stocks were identified as the most influential factors.

In another study done by Havasbeigi (1997), the value of stock and its intrinsic value during 1993-1996 based on Gordon model were compared. His main research hypothesis was that there is no significant difference between the transaction price and the intrinsic value. The results showed that in the years 1993 and 1994, there was a significant difference between the intrinsic value and the trading value, but in the years 1995 and 1996, there was a significant difference. This means that in the years 1993 and 1994, the model was efficient in the market and in 1995 and 1996, it was inefficient.

Mojtahedzadeh and Jahankhani (2003) introduced the model of stimulus value, free cash flow, and economic value added. They expressed that the discounted cash flows model shows the true value of companies through discounting future cash flows. But this method of determining the value does not provide meaningful scale for assessing companies' performance and progress. Finally, they introduced the model of economic value added and 
suggested that this model offers a clear principle for evaluating the performance of a new investment project or implementing a new strategy.

Also a lot of empirical research was done on the stock's price using different models. The models used include the random walk model and filter rules. In Random walk model, shortterm changes cannot be predicted and changes randomly move around their actual values. This does not mean that the price for a series of numbers is random; but basically, the prices are the best estimate for the true value. Theorists of this model argue that price changes are independent from each other and there is no correlation for price fluctuation. Price changes and thus returns are like a series of random numbers and cannot be predicted using past prices.

For the first time, Roberts (1959) stated that the diagram of a series of numbers that randomly extracted a series of charts is like stock prices. He suggested to the Chartists that if they look for a particular trend in both diagrams, they will find these points.

In another study by Osborne (1959) as a physicist, a number of stock prices were studied and it was found that these prices are consistent with the physical laws of motion of tiny particles. The variance of price changes in a relatively long time intervals increases with the square of the numbers over time. The concept of this increase was that the logarithm of the price changes is independent of each other. Fama (1970) also examined the daily stock price changes for 5 year and gained the correlation coefficient of $+0 / 03$.

Using regression analysis, flow test and variance ratio test on the weighted index of stock in Taiwan Stock Exchange, Locke (1995) found evidences to confirm random walk hypothesis. In short, all the evidences from empirical research confirmed random walk hypothesis and showed that changes in stocks prices are largely independent of each other.

\section{Research Hypotheses}

According to the chosen model, the following four hypotheses are formulated:

$\mathbf{H}_{1}$ : The price of stocks in Tehran Stock Exchange has no significant difference with the prices resulting from the application of present value model of future stock earnings.

$\mathbf{H}_{2}$ : The price of stocks in Tehran Stock Exchange has no significant difference with the prices resulting from the application of the Gordon Model with the fixed growth rate.

$\mathbf{H}_{3}$ : The price of stocks in Tehran Stock Exchange has no significant difference with the prices resulting from the application of Walter Evaluation Model.

$\mathbf{H}_{4}$ : The price of stocks in Tehran Stock Exchange has no significant difference with the prices resulting from the application of the model on the basis of price to book value $(\mathrm{P} / \mathrm{B})$.

\section{Method}

The methodology used in this study was quasi-experimental design. To test stock valuation models, ordinary least square regression was used. The data generally were collected using the information in website of Tehran Stock Exchange. In order to analyze data, EViews software was used due to its ability in ensuring the absence of correlation and heterogeneity of variance. The value of the Durbin-Watson (DW) was applied to test correlation and ARCH test was used to evaluate the absence of the problem of unequal variants in the regression. In 
addition, to determine the best model as well as the ranking, the adjusted coefficient of determination were employed and to test the basic conditions of regression equation, various tests such as t-test, LM test, Fuller test, and Perron test were used.

\section{Participants}

The study population included all companies listed in Tehran Stock Exchange which have been active in the Stock Exchange from 2008 till 2013. On the basis of stratified random sampling, each industry was selected as category and using Cochran formula, sample size of 40 participants was determined from each category. The statistical sample was selected from six industry including food industry, chemical industry, non-metallic products, motorcycle, and heavy metals.

For sample selection, the following criteria were considered:

1. Companies' information is available for all years studied;

2. The fiscal year ended to March;

3. Trading interval should not be more than six months;

4. and it should not relate to financial intermediation

\section{Research Models}

1) The present value of future stock returns

$$
P^{v}=\frac{D_{1}}{(1+K)^{1}}+\frac{D_{2}}{(1+K)^{2}}+\frac{D_{3}}{(1+K)^{3}}+\frac{D_{4}}{(1+K)^{4}}+\frac{D_{5}}{(1+K)^{5}}+\frac{D_{6}}{(1+K)^{6}}
$$

D1 ... D5 = stock dividend for a period of 6 years (2008 to 2013), P6 = stock price at the end of the sixth year, $\mathrm{K}=$ rate of return expected by investors on a five-year period

2) Gordon valuation model with constant interest rate in future

$$
P_{v+}=\frac{D 1}{(k-g)}
$$

$\mathrm{D} 1=$ profit of the first studied year, $\mathrm{k}=$ rate of return expected by investors, $\mathrm{g}=$ dividend growth rate

3) Walter valuation model

$$
P_{\nu}=\frac{D_{1}(E \operatorname{Br}) / \boldsymbol{k}}{R}
$$

$\mathrm{D}=$ Price per share, $\mathrm{E}=$ earnings per share, $\mathrm{r}=$ internal rate of return, $\mathrm{k}=$ Rate of return expected by investors

4) The price to book value $(\mathrm{P} / \mathrm{B})$

$$
\mathrm{P} / \mathrm{B}=\alpha_{0}+\alpha_{1} \text { Beta }_{\mathrm{it}}+\alpha_{2} \text { Growth }_{\mathrm{it}}+\alpha_{3} \mathrm{ROE}_{\mathrm{it}}+\alpha_{4} \text { Payout }_{\mathrm{it}}+\varepsilon_{\mathrm{T}}
$$

Beta $_{i t}=$ systemic risk, Growth ${ }_{\text {it }}=$ Dividend growth rate, Payout ${ }_{i t}=$ Percentage of dividend, $\mathrm{ROE}_{i \mathrm{t}}=$ return on equity 


\section{Data Collection}

To collect the required information, the questionnaires made by the researcher himself consisting of twenty-seven questions and also the stock valuation models were employed. To assess the reliability of valuation models questionnaire, Cronbach's alpha coefficient was used in SPSS software and the reliability was determined as $0 / 94$. To check the validity of the questionnaire, the content validity was used. For this purpose, five experts in management made their corrective recommendations to the questionnaire. In a preliminary test, 30 questionnaires were distributed among the population. Validity was verified by examining internal consistency and to analyze the data, both descriptive and inferential statistics were used. Descriptive statistics were used for the analysis of properties of the data collection and inferential statistics were used for statistical analysis of questionnaire. The research data of companies listed in Tehran Stock Exchange were gathered using the information website of Tehran Stock Exchange and also by the use of Tadbirpardaz software. Publications, annual reports and other reports of Tehran Stock Exchange, and audited financial statements of company were used too.

\section{Results}

$\mathbf{H}_{1}$ : Comparison of prices from the present value model of future cash flows with the market price assuming expected rate of return resulting from capital asset pricing

Table 1 shows the distribution frequency of the price difference resulting from the present value model of future cash flows compared to the market price assuming the expected rate of return resulting from capital asset pricing model.

Table 1

The Distribution Frequency of the Price Difference Resulting from the Present Value Model of Future Cash Flows Compared to the Market Price Assuming the Expected Rate of Return Resulting from Capital Asset Pricing Model

\begin{tabular}{lccccc}
\hline $\begin{array}{l}\text { The Range of Changes } \\
\text { (Percentage) }\end{array}$ & $\begin{array}{c}\text { The Difference of the Theoretical } \\
\text { Value with the Base Price }\end{array}$ & $\begin{array}{c}\text { Number of } \\
\text { Companies }\end{array}$ & $\mathrm{f}$ & $\mathrm{Fc}$ & $\mathrm{fc}$ \\
\hline Less than- 20\% & $\mathrm{PV}<\mathrm{P} 0$ & 14 & 0.35 & 14 & 0.35 \\
Between $20 \%$ to 0 & $\mathrm{PV}>\mathrm{P} 0$ & 6 & 0.15 & 20 & 0.5 \\
Between 0 to $20 \%$ & $\mathrm{PV}>\mathrm{P} 0$ & 2 & 0.05 & 22 & 0.55 \\
More than 20\% & $\mathrm{PV}<\mathrm{P0}$ & 18 & 0.45 & 30 & 1 \\
\hline
\end{tabular}

Table 1 represents that in eight companies (20\% of all companies), valuation model offered a price nearly similar to market price (with a difference of $20 \%$ ), eighteen companies $(45 \%$ of all companies) valuation model offered a price more than the market price (more than a difference of $20 \%$ ), and in fourteen companies (35\% of all companies) valuation model offered a price less than the market price (more than a difference of 20\%).

The most expensive market price compared to the valuation model was related to Pars and Primrose chemical company and the cheapest price was related to Fiber Company.

$\mathbf{H}_{2}$ : Comparison of the price of the Gordon model with the market price assuming the rate of return of the capital resulting from capital asset pricing model 
Table 2 presents the frequency distribution of the price difference resulting from Gordon model compared to market price assuming expected rate of return resulting from capital asset pricing model

Table 2

The Frequency Distribution of the Price Difference Resulting from Gordon Model Compared to Market Price Assuming Expected Rate of Return Resulting from Capital Asset Pricing Model

\begin{tabular}{lcccc}
$\begin{array}{l}\text { The Range of Changes } \\
\text { (Percentage) }\end{array}$ & $\begin{array}{c}\text { The Difference of the } \\
\text { Theoretical Value with the } \\
\text { Base Price }\end{array}$ & $\begin{array}{c}\text { Number of } \\
\text { Companies }\end{array}$ & $\mathrm{f}$ & $\mathrm{Fc}$ \\
\hline Less than- $20 \%$ & $\mathrm{PV}<\mathrm{P} 0$ & 20 & 0.5 & 20 \\
Between $20 \%$ to 0 & $\mathrm{PV}>\mathrm{P} 0$ & 3 & 0.75 & 23 \\
Between 0 to $20 \%$ & $\mathrm{PV}>\mathrm{P} 0$ & 2 & 0.5 & 25 \\
More than $20 \%$ & $\mathrm{PV}<\mathrm{P} 0$ & 15 & 0.375 & 40 \\
\hline
\end{tabular}

Table 2 reveals that in five companies (12.5\% of all companies) Gordon model offered a price nearly similar to market price (with a difference of $20 \%$ ), in fifteen companies $(37 / 5 \%$ of all companies) the model offered a price more than the market price (more than a difference of $20 \%$ ), and in 20 companies (50\% of the companies), the model offered a price less than the market price (more than a difference of $20 \%$ ).

The most expensive price compared to price model was related to Hekmatan Sugar Company and the cheapest price was related to Paxan Company.

$\mathbf{H}_{3}$ : Comparison of the price resulting from Walter model with market price assuming a rate of return resulting from the capital asset pricing model

Table 3 illustrates the frequency distribution of the price difference resulting from Walter model compared to assuming a rate of return resulting from the capital asset pricing model.

Table 3

The Frequency Distribution of the Price Difference Resulting from Walter Model Compared to Assuming a Rate of Return Resulting from the Capital Asset Pricing Model

\begin{tabular}{|c|c|c|c|c|c|}
\hline 0 to $20 \%$ & $\mathrm{PV}>\mathrm{P} 0$ & 8 & 0.2 & 23 & 0.375 \\
\hline 0 to $20 \%$ & $\mathrm{PV}>\mathrm{P} 0$ & 2 & 0.05 & 25 & 0.425 \\
\hline
\end{tabular}

Table 3 shows that only ten companies ( $25 \%$ of all companies) of Walter Model offered a price nearly similar to the market price (with a difference of $20 \%$ ), twenty three companies (57.5\% of all companies) of the model offered a price more than the market price (more than a difference of $20 \%$ ), and in seven companies (17.5\% of all companies), the model offered a price less than the market price (more than a difference of $20 \%$ ). 
Meanwhile, the most expensive price compared to the market price was related to the Hekmatan Sugar Company and cheapest price was related to Fiber Company.

$\mathbf{H}_{4}$ : The result of P/B model indicated that the company's growth and return on equity played a significant role in determining the $\mathrm{P} / \mathrm{B}$ ratio. The coefficient of determination for several years is arranged as $29 \%, 45 \%, 76 \%, 81 \%, 51 \%, 80 \%$, respectively which is relatively high. Adjusted coefficient of determination for the combined data was $80 \%$. The results obtained from this model are compatible with Damodaran's results (1996).

$$
\mathrm{P} / \mathrm{B}=\alpha_{0}+\alpha_{1} \text { Beta }_{\mathrm{it}}+\alpha_{2} \text { Growth }_{\mathrm{it}}+\alpha_{3} \mathrm{ROE}_{\mathrm{it}}+\alpha_{4} \text { Payout }_{\mathrm{it}}+\varepsilon_{\mathrm{T}}
$$

Table 4 presents the results of $\mathrm{P} / \mathrm{B}$ Ratio.

Table 4

The Results of P/B Ratio

\begin{tabular}{|c|c|c|c|c|c|c|c|}
\hline $\begin{array}{l}\text { Durbin- } \\
\text { Watson }\end{array}$ & $\begin{array}{l}\text { The coefficient } \\
\text { of determination }\end{array}$ & Payoutit & ROEit & Growthit & Betait & $\alpha 0$ & Year \\
\hline \multirow[t]{2}{*}{2.12} & 0.80 & 0 & 3.72 & -0.78 & 0.02 & 0.63 & Pool \\
\hline & & $(0.02)$ & $(11.24)^{* *}$ & $(-3.22)^{* *}$ & $(0.3)$ & $(6.4)^{* *}$ & \\
\hline \multirow[t]{2}{*}{1.78} & 0.78 & 0.01 & 14.16 & -3.19 & -0.15 & -1.65 & 1387 \\
\hline & & $(0.4)$ & $(12.22)^{* *}$ & $(-1.47)$ & $(-0.2)$ & $(-0.98)$ & \\
\hline \multirow[t]{2}{*}{1.97} & 0.46 & -0.01 & 8.03 & 2.59 & -3.7 & 1.75 & 1388 \\
\hline & & $(-0.31)$ & $(6.74)^{* *}$ & $(0.94)$ & $(-1.9)^{*}$ & $(1.35)$ & \\
\hline \multirow[t]{2}{*}{2.39} & 0.80 & -0.01 & 10.39 & 0.2 & -0.85 & -0.97 & 1389 \\
\hline & & $(-1.74)$ & $(13.99)^{* *}$ & $(0.14)$ & $(-1.19)$ & $(-1.8)$ & \\
\hline \multirow[t]{2}{*}{2.37} & 0.74 & 0 & 8.27 & -2.42 & -0.36 & -0.34 & 1389 \\
\hline & & $(-0.73)$ & $(12.06)^{* *}$ & $(-1.56)$ & $(-0.51)$ & $(-0.69)$ & \\
\hline \multirow[t]{2}{*}{2.19} & 0.40 & 0 & 4.5 & -0.15 & 0.03 & 0.5 & 1390 \\
\hline & & $(0.72)$ & $(4.81)^{* *}$ & $(-0.18)$ & $(0.22)$ & $(1.71)^{*}$ & \\
\hline \multirow[t]{2}{*}{2.09} & 0.22 & 0 & 3.1 & -2.56 & 0.69 & 0.89 & 1392 \\
\hline & & $(-.27)$ & $(2.73)^{* *}$ & $(-2.61)^{* *}$ & $(2.62)^{* *}$ & $(2.82)^{* *}$ & \\
\hline
\end{tabular}

Note: $*$ and $* *$ show the error level of $1 \%$ and $5 \%$, respectively and the numbers in the parentheses indicate the size of the t-statistic.

\section{Conclusion}

The aim of this study was to compare the price of stocks in Tehran Stock Exchange with the prices resulting from various theoretical models. In this regard, four valuation models introduced in the theory of financial management were selected and real information of the companies was placed in each of the models during study period and stock prices obtained from the model were compared with the market price and finally it was observed that there was no conformity between prices in the market with the prices of the models. Some factors including the inability of the market to provide timely and useful information to predict future cash flows, investors' unawareness of theoretical models of valuation, investors' inability, the use of information and financial indicators to measure the expected rate of return and investment risk, emerging capital market, and high risk of investment by managers are among the most important factors upon which the truth behind activities of the market of securities transactions is different from the theoretical foundations. 
In this study, according to the estimated regression equation for the companies operating in Tehran Stock Exchange based on monthly data of 2008-2013 for a period of six years, the relationship between the stock price and the intrinsic value of stocks using theses four models is included as follows:

Greater $t$-value of variable coefficient of stock value as well as significant $F$ represents that it is influenced by the changes in the intrinsic value of the stock price within the framework of the CAPM model.

According to the definition of the efficiency of the stock market, if their efficiency which is affected by changes in stock prices yield significant relationship with their performances in the past, the market is inefficient. The companies which have significant beta, if they come into account as example, it happens only for Sufian cement companies, Alborz investment SAIPA, petrochemical investment and Qazvin glass. Therefore, the market has no required efficiency.

However, when the stock price changes are due to the intrinsic value of stock, it implies the market efficiency. So, according to the above criteria, the market is efficient. In justifying observed contradiction, it should be noted that efficiency is searchable in a static and dynamic context. Thus, if in a given time period, e.g. April 2014, there was a significant relationship between stock price and intrinsic value, it is concluded that Tehran Stock Exchange in April 2014 was statically efficient. In this context, regulation policies of stock market should be focused on providing dynamic efficiency. On the other hand, the stock market at a specific time (in this study, the years 2008-2013) was inefficient because of the relationship of stock returns at a particular period with the previous period. In general, the market at a specific time period can be effective but not efficient in a long-term period.

As mentioned above, in most of the surveyed companies, stock returns had a significant relationship with its past returns. However, according to ECM model, when the ECT coefficient which represents the speed of adjustment is close to -1, it indicates that a large amount of errors of earlier period have been adjusted in each period. Therefore, the adjustment to the balance is done quickly. In the current study, ECT coefficient of the companies is close to -1 . Thus, the errors of the prior period are adjusted in the current period and people in shaping their expectations largely do not repeat past errors. That is, the speed of adjustment of errors in the adaptive expectations model is high. Based on the research results, none of these valuation models (model 1,2, and 3) provide a price close to market prices. And, in the comparison of the results, it can be concluded that in case of the rate of the return of capital asset pricing model, the price resulting from Walter model is closer than the other two models to the market price. This model provides a sample price close to the market price for ten companies from forty companies, whereas this number is indicative of the present value of future cash flows of eight companies and also five companies using Gordon model.

In the case of using the expected rate of return resulting from capital asset pricing model, it is observed that in the present value of future cash flows models and Walter model, the price resultant from the model is more than the market price for most companies and only Gordon model provides a price less than the market price; so that the price resultant from the present value model of future cash flows for eighteen companies, i.e. $45 \%$ of the all 
companies is more than the market price and for the fourteen companies, i.e. $35 \%$ of all companies is less.

The price resultant from Gordon model for twenty companies, i.e. $50 \%$ of all companies are less than the market price and the price resultant from Walter model for twenty three companies i.e. $57.5 \%$ of all companies is more than the market price.

In Iran, variables of earnings per share, dividend per share, systemic risk, net profit margin, and return on equity are the major factors in determining stock prices of listed companies in Tehran Stock Exchange.

To activate the stock market, it is recommended that Tehran stock exchange officials refrain as much as possible to determine the base price of stock and leave it to the professional independent organization. Following this, if it is inevitable to determine the base price of the stock at the absence of these organizations, it is suggested that according to the analysis of the mentioned industry and company, discount rate appropriate to the risk of investing in stocks must be calculated as well as the growth rate of future earnings commensurate with the increase of the strength of corporate profits and using a relevant formula, the value of each stock must be determined.

Instead of controlling the fluctuation of stock prices in the stock market, it will be better to provide an appropriate condition for the professionals to be active in market and gradually increase the number of people who have the expertise to assess the stock. Given that the value of the stock is not possible without accurate and timely information, the management of stock exchanges should make highly intensive efforts to persuade or compel the company to release the right information and the information should be updated for the short periods of three months too. Following this, the stock exchange should provide the condition of creating financial service institutions and investment companies which their main tasks are the analysis of political, economic, and financial information and make recommendations for buying and selling stocks. Managers and planners of Stock Exchange as well as economic planners should adopt appropriate strategies to achieve efficiency in stock exchange as the infrastructure of investment development. Investors with analytical review of data and estimates of future status should intend to buy or sell them and also, the non-quantitative factors should be considered in the future studies.

\section{References}

Banz, R. W. (1981). The Relationship between return and market value of common stock Journal of Financial Economics, 9(1), 3-18.

Basu, S. (1977). Investment performance of common stocks in relation to their price-earnings ratios: A test of the efficient market hypothesis. The Journal of Finance, 32(3), 663-682.

Blume, M. E., \& Friend, I. (1973). A new look at the capital asset pricing model. Journal of Finance, 28(1), 19-33.

Capaul, C., Rowley, I., \& Sharpe, W. F. (1993). International value and growth returns. Financial Analysts Journal, 49(1), $27-36$.

Chan, L. K. C., Hamao, Y., \& Lakonishok, J. (1991). Fundamentals and stock returns in Japan. Journal of Finance, 46, 1739-1764.

Damodaran, A. (1996). Investment valuation: Tools and techniques for determining the value of any asset. New York: John Wiley \& Sons.

Fama F. E. (1970). The behavior of stock market prices. Journal of Business, 38, 34-105. 
Fama, E. F. (1991). Efficient Capital Markets: II. The Journal of Finance, 46, 1575-1617.

Fama, E. F., \& MacBeth, J. D. (1973). Risk, return, and equilibrium: Empirical tests, Journal of Political Economy, 81(3), $607-636$.

Fama, E. F., \& French, K. R. (1992). The cross-section of expected stock returns, Journal of Finance, 47(2), 427-465.

Fama, E. F., \& French, K. R. (1995). Size and book-to-market factors in earning and return, Journal of Finance, 51, 55-84.

Frankel, R., \& Lee, C. (1998). Accounting valuation, market expectation and the book to market effect. Journal of Accounting Research, 25, 283-319.

Havasbeigi, R. (1997). Comparison of stock valuation theories with the actual process of price changes in the stock exchange (Unpublished master's thesis). Tehran University, Iran.

Kapalan, S., \& Ruback, R. (1995). The valuation of cash flow forecasts: An empirical Analysis. Journal of Finance, 50, 1059-1094.

Locke, E., A. (1995).Beyond determinism and materialism, or isn't it time we took consciousness seriously? Journal of Behavior Therapy \& Experimental Psychiatry, 26, 265-273.

Mojtahedzadeh, V., \& Jahankhani, A. (2003). Valuation of companies. Tehran: Rahbord Press.

Osborne, M. F. M. (1959). Brownian motion in the stock market. Operations Research, 7, 145-73.

Panahi Jahanabad, A. (2007). Evaluation of systemic risk in Tehran Stock Exchange (Unpublished master's thesis). Allameh Tabatabai University, Iran.

Rao Romesh, K. S. (1989). Fundamentals of financial management. India: Maxwell, Macmillan.

Roberts, H. V. (1959). Stock market patterns and financial analysis: Methodological suggestions. Journal of Finance, 14-10.

Salami, A. B. (2002). Turbulence testing in the returns of stocks in Tehran Stock Exchange. Economic Research Journal, 5 , $35-73$.

Shafizadeh, A. (1996). The relationship between systematic risk and stock returns (Unpublished master's thesis). Tehran University, Iran.

Sorensen, E. H., \& Williamson, D. A. (1980). Some evidence on the value of the dividend discount model. Financial analyst Journal, 41, 60-69.

Stambaugh, R. (1982). On the exclusion of assets from tests of the two- parameter model: A sensitivity analysis. Journal of Financial Economics, 10(3), 237-268.

Stewart, G. B. (1990). Announcing the Stem Stewart performance 1000: A new way of viewing corporate America. Journal of Applied Corporate Finance, 3, 38-55.

Tahmasbi, D. (1998). Determining the intrinsic value of the stock for automobile industry in Tehran Stock Exchange (Unpublished master's thesis). Allameh Tabatabai University, Iran.

Tehrani, R. (1995). Factors affecting the price of shares in Tehran Stock Exchange (Unpublished doctoral dissertation). Tehran University, Iran.

Vaez, M., Abzari, M., \& Jamali, S. J. (1991). The feasibility of Tehran Stock Price index forecasting by using CAPM model. Journal of Knowledge and Development, 15, 49-71. 